\title{
RCM DEPLOYMENT ANALYSIS IN FIBER WOOD PRODUCTION: IMPROVING THE PRODUCTIVITY AND INCREASING THE SYSTEM RELIABILITY
}

\author{
Flávio Piechnicki \\ IFPR - Instituto Federal do Paraná PUC-PR - Pontifícia \\ Universidade Católica do Paraná, Brazil \\ E-mail: flavio.piechnicki@ifpr.edu.br
}

Cleiton Santos PUC-PR - Pontifícia Universidade Católica do Paraná, Brazil E-mail: cleiton.ctba@hotmail.com

Eduardo Loures PUC-PR - Pontifícia Universidade Católica do Paraná, Brazil E-mail: eduardo.loures@pucbr.br

Eduardo Santos PUC-PR - Pontifícia Universidade Católica do Paraná, Brazil E-mail: eduardo.santos@pucbr.br

Submission: 2/26/2019 Accept: $3 / 28 / 2019$

\section{ABSTRACT}

The maturity of the current production systems allocates the company in scenarios of success or not in achieving the goals of the business. It is enhanced through the use of tools and methodologies to support decision-making in all layers and sectors of the company. In this scenario, researches on the maintenance management are so relevant because its objectives affect directly system reliability, indicators of quality, safety requirements, environmental impacts and operating costs. Selecting the right maintenance policy has become one of the most important decisionmaking actions in the industry. In contemporary maintenance techniques, Reliability Centered Maintenance (RCM) is a systematic process that analyses the functions and potential failures of a physical asset, with focus on the preservation of the systems functions. In this context, the present paper investigates the RCM models in the literature concentering in the methodologies applied and in practical approaches. 
DOI: 10.14807/ijmp.v10i6.1009

Based on this, a customized deployment model was proposed combining techniques and tools in a structured methodology for the selection of maintenance actions. The steps and details of the implementing are enhanced with a practical approach in multiple case studies in different industrial sectors. Results of the increase of the systems reliability are validated by a failure rate analysis before and after each application. More, questions about security, environment and costs are highlighted, generating a new knowledge base and promoting continuous discussions in order to improve all the process involved.

Keywords: Reliability Centered Maintenance, Maintenance Strategies, Failure analysis, Pulp mill, Fiber wood, Case Study.

\section{INTRODUCTION}

Globalization, increased levels of automation of industrial processes and the ambition to production best practices increase the demand for an increasingly effective maintenance (SALONEN; DELERYD, 2011). According to Samet et al. (2010), the performance of a strategy is usually evaluated in terms of the average total cost at a particular horizon in terms of availability or production system. Thus, the maintenance policies to be employed in an industry or process should be carefully selected because they have a direct impact on costs.

For Tsarouhas (2011) the purpose of maintenance strategy is to increase the time between failures and reduce repair time. Thus, it is expected that effective maintenance policies can and, in fact, reduce the frequency of interruptions for maintenance and avoid the most undesirable consequences of such interruptions.

Traditional maintenance policies spread the belief that all faults are dangerous and should be avoided. However, a detailed analysis confronts this statement in two ways:

(i) often, the technical point of view, it is not feasible to avoid a failure;

(ii) even if all failures could be avoided, what would be the cost of this action?

In this scenario emerges the RCM methodology that, according to Deshpande and Modak (2002), provides a framework capable of reducing maintenance activities and costs related to them as far as possible without affecting the performance of the plant, product quality, safety or environmental integrity. 
INDEPENDENT JOURNAL OF MANAGEMENT \& PRODUCTION (IJM\&P)

http://Www.ijmp.jor.br

v. 10, n. 6, November-December 2019

ISSN: 2236-269X

DOI: 10.14807/ijmp.v10i6.1009

However, for the RCM deployment success, aspects should be observed of each conceptual model and the specific variables of the industrial system selected. This perception becomes difficult for the diversity of technologies involved the MMIS (Maintenance Management Information Systems), the organizational aspects and the maintenance structure as a whole.

Thus, the creation of customized models with references in the RCM standards increases the chances of implementation successful. Still, the application of models in real industrial systems highlights the difficulties and explains the need for a good initial planning, a structured and organized deployment and a suitable program of continuous improvement.

This paper is organized as follows. Section 2 introduces a review about the RCM methodology, with a historical overview with emphasis in the standards created to different approaches. Some questions that are expected to be answered with the RCM methodology are commented and a generic deployment model is introduced. Section 3 exposes towards of the deployment model used in the present paper.

The evolution steps are detailed, since the study preparation until the continuous improvement monitoring. Finally, Section 4 presents the deployment model applied in a fiber wood production system. The steps are implemented detail, and the results are presented and discussed.

\section{RCM BACKGROUNDS}

The Reliability Centered Maintenance emerged in the late 60s, initially targeted for the aviation industry, with the aim of directing the efforts of the maintenance for components and systems where reliability is critical. Its main objective is to ensure that performance, safety and environmental protection are cost-effective (MOUBRAY, 1997; SIQUEIRA, 2009; WANG; HWANG, 2004).

The aviation industry has been the forerunner in research reliability and effects of failures in maintenance, in order to meet the requirements of the FAA (Federal Aviation Agency), which was concerned about the high rate of failure in the engines of the Era's aircraft. In the late 60s, the ATA (Air Transport Association of America) created the MSG (Maintenance Steering Group), a task force to review the application of existing methods and maintenance techniques for aircraft maintenance (BACKLUND, 2003; SIQUEIRA, 2009). 
INDEPENDENT JOURNAL OF MANAGEMENT \& PRODUCTION (IJM\&P)

http://Www.ijmp.jor.br

v. 10, n. 6, November-December 2019

ISSN: 2236-269X

DOI: 10.14807/ijmp.v10i6.1009

In the early 70s, Nowlan and Heap, subject to the ATA, published the MSG-1 standards and MSG-2 presenting a new way in the approach to maintenance for aircraft, focusing on the impact of the lack of reliability in operation and safety, methodology that became known with Reliability-Centered Maintenance (GARZA, 2002).

The MSG-3, 1980, included the previous standards, and a joint vision of the entire aircraft industry process being adopted as a mandatory methodology maintenance for new aircraft by the US Department of Defense - DoD, which is currently used after last reviewed in 2002 (SIQUEIRA, 2009).

Industrial needs of the 80s led to the implementation of RCM in other sectors of industry, especially in the mining and manufacturing (BACKLUND, 2003). This spreading of the SPC motivated the appearance of slightly different versions of the MSG-3. The evolution of the initiatives about the RCM methodology resulted in the publication of the MSG-III, as proposed by RCM-II (MOUBRAY, 1997), Classical Abbreviated SPC and the Experience-Centered Maintenance (ECM) (HINCHCLIFFE; SMITH, 2004). It is a modern approach, now a proven and accepted methodology used in wide range of industries.

Studies have been found in the literature, generally, with combinations of techniques and tools around de reliability context. Some of them define a detailed deployment model, exploring it step by step. Dehghanian et. al. (2013) proposes a comprehensive scheme for RCM, with a methodology composed for ten steps that is applicable for Power Distribution Systems.

Fore and Mudavanhu (2016) applied a RCM model with seven steps and applicable for a Chipping and Sawing Mil. It perceives that the related works are most often applied for a specific system. Other initiatives are found with applications for different types of industry (SRIKRISHNA et. al., 1996; BAE et. al., 2009; FISCHER et. al., 2012; PARK; YOON, 2012; MORAD et. al., 2014; HEO et. al., 2014; SINHA; MUKHOPADHYAY, 2015).

Gupta and Mishra (2016) purposes a SWOT (Strengths, Weaknesses, Opportunities and Threats) analysis and applied the model in different frameworks to identify the important factors for RCM implementation. However, this work presents a 
DOI: 10.14807/ijmp.v10i6.1009

structured and detailed deployment model, with a contemporary approach and multiple case studies.

According to Moubray (1997), when deployed correctly, the RCM will reduce the routine maintenance tasks from $40 \%$ to $70 \%$, with a number of advantages and benefits in security, logistics, operation and management of organizations.

The RCM approach seeks to answer seven questions presented sequentially on the system or process analysis (BACKLUND, 2003 and MOUBRAY, 1997):

(i) What functions should be preserved?

(ii) What are the functional failures?

(iii) What are the Failure Modes?

(iv) What are the effects of failure?

(v) What are the consequences of failure?

(vi) What are the applicable and effective tasks?

(vii) What are the other alternatives?

Siqueira (2009) proposes an additional issue in order to optimize the frequency calculation of activities:

(viii) What is the ideal frequency for the task?

To answer these questions systematically, RCM implementation process in maintaining a device or system can be summarized in steps (MOUBRAY, 1997; SIQUEIRA, 2009; SMITH; HINCHCLIFFE, 2004). The process of analysis and possible relationships that might be present at each stage of deployment will be presented below.

\section{TOWARDS A RCM DEPLOYMENT}

$\mathrm{RCM}$ is a methodology used in industries with strong barriers as regards users (human factors) and safety levels. The deployment must be performed according to the operational and organizational context, observing its products, processes and procedures. In spite of being a standard approach, the RCM can be customized to particular requirements and constraints of the industry where it is applied. The 
INDEPENDENT JOURNAL OF MANAGEMENT \& PRODUCTION (IJM\&P)

http://Www.ijmp.jor.br

v. 10, n. 6, November-December 2019

ISSN: 2236-269X

DOI: 10.14807/ijmp.v10i6.1009

adaptations of the RCM application are discussed here. It should be noted that risk studies in the RCM analysis must also be considered when defining the methodology.

The present study proves that the analysis of these factors is very important, and is highlighted to make easier and more reproductive the RCM approach.

Considering the above issues, is proposed a RCM deployment program, whose steps are shown in Figure 1.

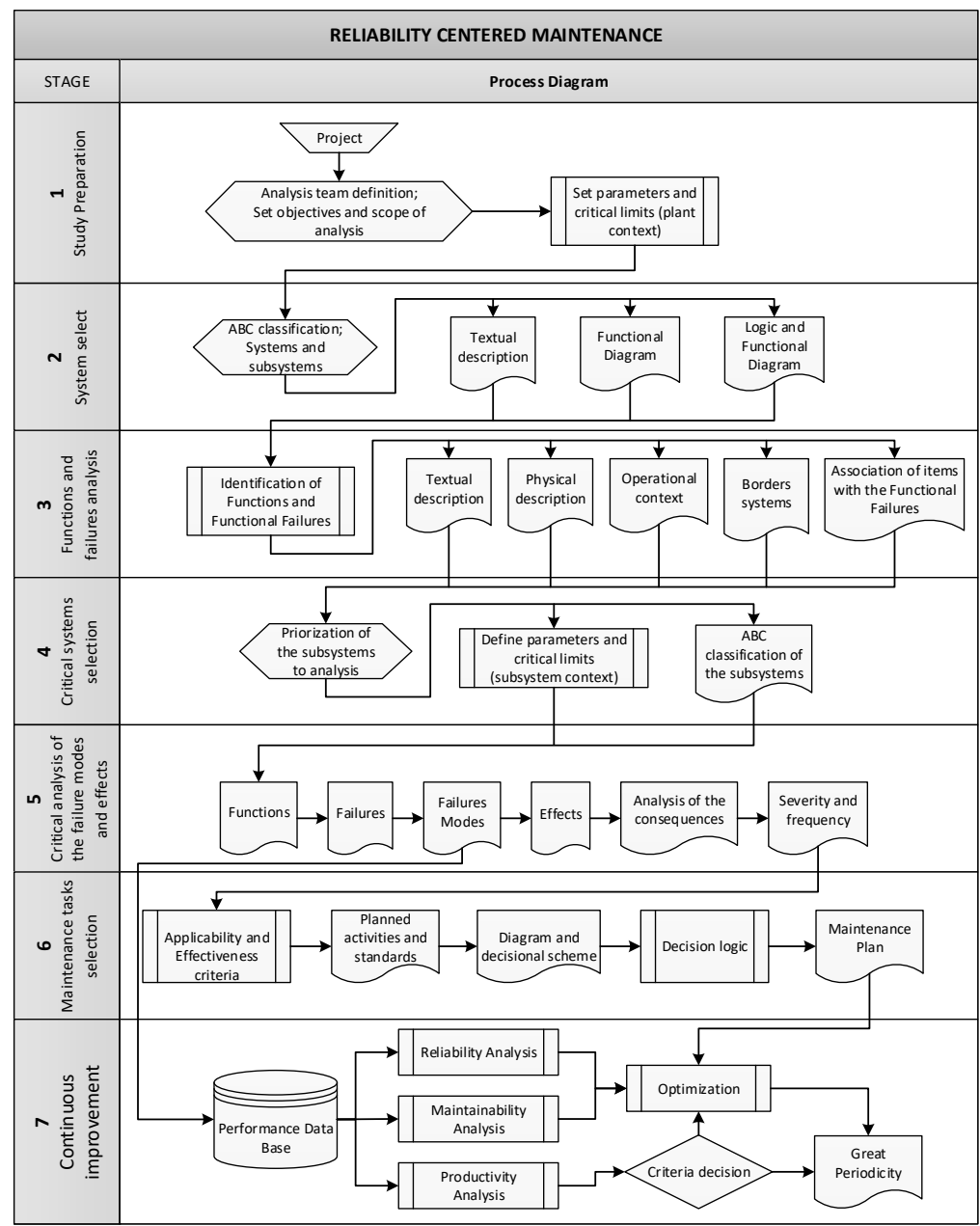

Figure 1: RCM Deployment Model (Adapted from SIQUEIRA, 2009)

\subsection{Study Preparation}

This stage of the implementation refers to the formation of technical staff, and allocation of responsibilities. The objectives and scope of application of study should have been defined in the context of plant or asset considered in the study. They are certain critical parameters of the plant, as well as its operating parameters.

Manuals and operating instructions can be used for this purpose, as well as performance standards, design specifications, supplier manuals, fault data, 
DOI: 10.14807/ijmp.v10i6.1009

maintenance requirements, operating diagrams and technical drawings of the facility including its interfaces with other systems (NAVSEA, 2007; SMITH; HINCHCLIFFE, 2004).

\subsection{System Selection}

For system selection, the standard NAVAIR 00-25-403 (2005) suggests considering as priority systems those with impact on safety, the environment, operation and cost. Smith and Hinchcliffe (2004) add as criteria the volume and cost of the tasks of preventive maintenance, corrective maintenance with high cost or frequency and systems with a large impact on production downtime. The identification systems is a key part of the RCM, as the functions and system failures will be based on the result of this step.

\subsection{Analysis of functions and failures}

The system functions (identified by their output interfaces) define the maintenance activities required for each system. Moubray (1997) points out that this identification will be complete only when combined with a desired level of performance for each function. For Mobley et al. (2008), defining the role is to describe the actions or requirements that the system or subsystem must perform in terms of performance and capacity within the specified limits, identifying them for all equipment operating modes.

Moubray (1997) suggests dividing Identified system functions and its subsystems into two main categories: (i) primary or main functions; and (ii) secondary or auxiliary functions. Smith and Hinchcliffe (2004) highlight two key points in this stage of the process: (i) the focus of the analysis is the loss of function rather than loss of equipment; (ii) failures are more than just a single, simple statement of loss of function, because most functions have two or more loss conditions were not all are equally important.

\subsection{Selection of critical systems}

For Sautter and Wessels (2009) a criticality analysis provides a final evaluation of the effects of a Failure Mode and may be conducted in a qualitative or a quantitative approach. The quantitative approach is to achieve a critical number from failure rates, Failure Modes of rate effects, rate of failures with known and trusted values (See MILSTD-1629A and IEC 60812 that presents methods and formulas to use this approach). 
INDEPENDENT JOURNAL OF MANAGEMENT \& PRODUCTION (IJM\&P)

http://Www.ijmp.jor.br

v. 10, n. 6, November - December 2019

ISSN: 2236-269X

DOI: 10.14807/ijmp.v10i6.1009

The qualitative method is used when there is no data available on the flaws, it is necessary to classify the criticality by team members in a subjective way, and common adoption in projects or facilities in the commissioning phase. However, as the system matures, data collection and the use of quantitative methods are recommended (IEC, 2006).

One method for assessing criticality is the use of the Risk Priority Number (RPN). Jian-Ming et al. (2011) note that the RPN is used to analyze the risks associated with potential failures, focusing on prioritization of maintenance actions. The evaluation of the RPN can be performed using equation 1 or when the detection level used by the Equation 2 (IEC, 2006; HUADONG; ZHIGANG, 2009).

$$
\begin{aligned}
& R P N=S \times F \\
& R P N=S \times F \times D
\end{aligned}
$$

(S) expresses the severity of Failure Mode, (F) the frequency and (D) the level of detection. The latter measures the difficulty in detecting, by evaluating detection methods available and their applicability for each failure or Failure Mode analysis. A failure that does not allow detection receives a high value on the scale, because the probability of detection is low (HUADONG; ZHIGANG, 2011; MCDERMOTT et al., 2009).

Once the criticality analysis is finished, whether quantitative or qualitative, Failure Modes should be selected through a ranking, with a decreasing presentation of the Failure Modes depending on the RPN. It can be used as a selection tool, the criticality matrix or array of values in tables (HEADQUARTERS, 2006; IEC, 2006). McDermott et al. (2009) note the use of the "80/20" rule associated with a Pareto diagram as another tool to aid in selection of the Failure Modes.

\subsection{Critical analysis of Failure Modes and effects}

Almannai et al. (2008) define FMEA (Failure Mode and Effect Analysis) as a systematic approach focusing on prevention of failures of a system, project and / or process. It uses an approach identification, frequency and impact of Failure Modes on them.

The FMEA process is a sequence of logical steps which begins with the analysis of lower level elements (subsystems or components), identifying potential 
DOI: 10.14807/ijmp.v10i6.1009

Failure Modes and failure mechanisms, tracing its effects on various system levels (MOBLEY, 1999). This tool consists of a collection of information, in document creation and reporting. This information should be documented in a spreadsheet that will ensure the documentation of the Failure Modes associated with each functional failure, its causes and effects, helping also in the analysis of maintenance actions RCM (KIM et al., 2009; ZAIONS, 2003).

\subsection{Selection of maintenance activities}

The purpose of this step is to select the preventive maintenance activities based on their applicability and effectiveness. It should be analyzed their ability to reduce, eliminate, prevent or detect a failure reconciled to economic feasibility and technical analysis of the same. The analysis of the consequences of failure should be held in the RCM as a result of the evaluation of its impact on the following factors: (i) Security; (ii) Environment; (iii) Operation and (iv) Economic (NAVSEA 2007; SMITH, 1993).

Chosen the significant functions, RCM methodology uses a structured logic driven through a decision flow, based on a series of questions about the functional failure and Failure Modes associated with it. This will help to determine the need and frequency of preventive and other maintenance tasks (NAVSEA, 2007; NASA, 2008).

Traditionally, the RCM's decision process occurs at three levels: effects, consequences and causes. It represents, respectively, an inquiry into: (i) the evidence of function loss; (ii) its consequences: safety, environmental, operational or economic; and (iii) analysis of tasks.

Zaions (2003) notes the use of a decision tree based on the evaluation of the evidence and consequence of failure and logical analysis of the activities. Figure 2 (MOUBRAY, 1997) shows a decision-making flow for selecting the maintenance activity. The decision flow is based on a series of questions which, according to the answer provided by the analyst, will lead to selection of a maintenance activity.

The information in decision-making should be stored in a form containing: the responses of the Decision Diagram, detailed description of the selected activities, technical information, frequency and responsibility for implementation. 
ISSN: 2236-269X

DOI: 10.14807/ijmp.v10i6.1009

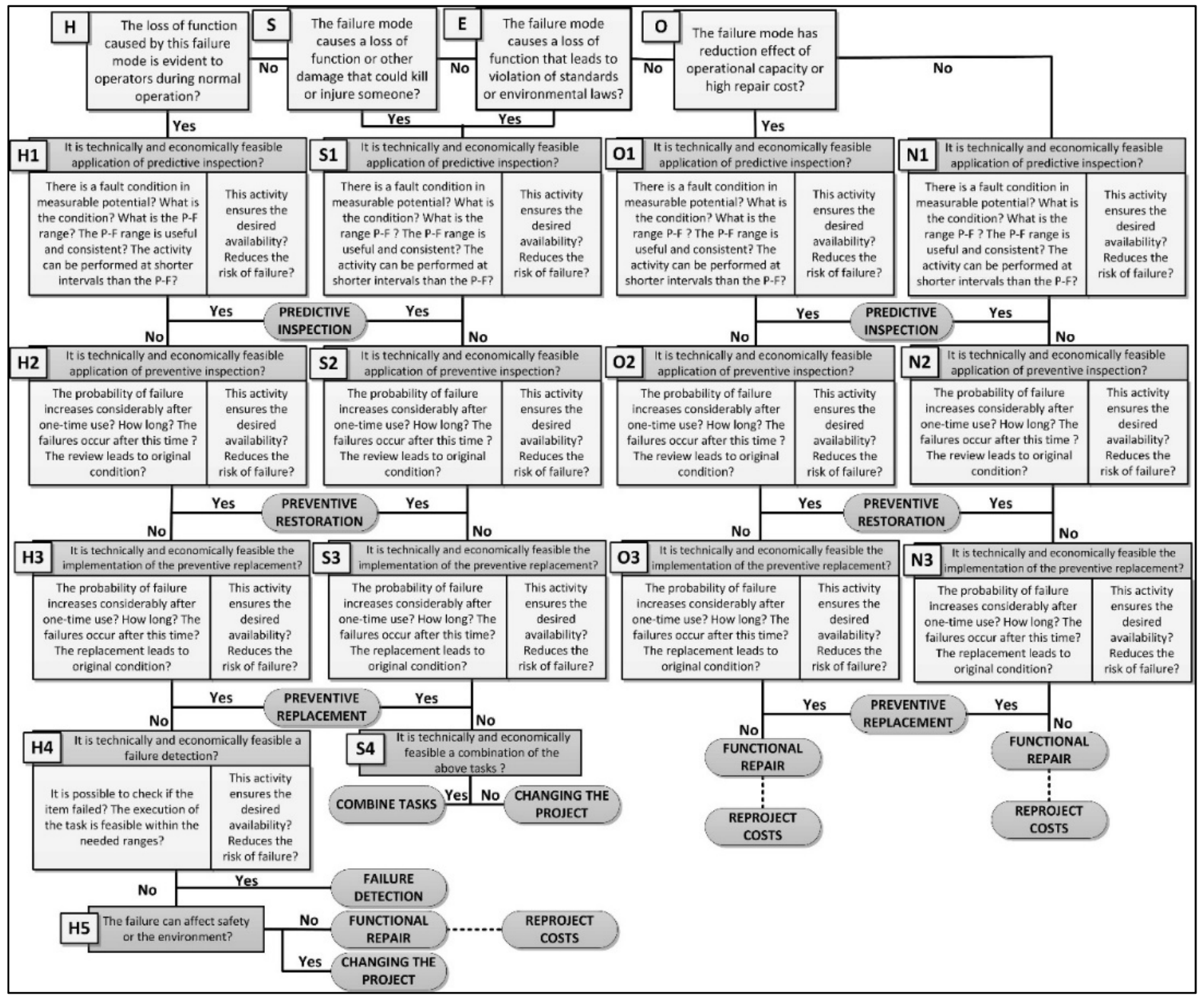

Figure 2: Decisional Diagram (MOUBRAY, 1997)

After this analysis, the result must be documented in a form, assisting in the implementation sequence, forming a historical system for future audits (NAVAIR, 2005).

\subsection{Continuous Improvement}

Throughout the process of RCM analysis and after its completion, is important the formation of a group responsible for the audit and reporting possible updates and fixes to improve the methodology. This study group have to be able to answer questions about reliability, maintainability and productivity of process studied. The objective is to feed back the RCM program, to optimize continuously the maintenance tasks and to reach a great periodicity, increasing the system performance.

Smith and Hinchcliffe (2004) point the following topics for the adoption of a continuous improvement program RCM: (i) the RCM process is not perfect, and may require periodic adjustments to the reference results; (ii) the system or plant may 
DOI: 10.14807/ijmp.v10i6.1009

change, as change projects, including equipment, technical or operational changes that emerge from the results of analysis; (iii) the knowledge acquired during the process of analysis and implementation can be useful in revalidation of results.

Smith (1993) points out the following steps to a continuous improvement program RCM process: (i) adjustment of test results, (ii) plant modification or system; (iii) new information; and (iv) measuring the implantation results.

\section{CASE STUDY}

The assessment of applicability and efficacy of RCM model was performed by a case study. Thus, the proposed deployment model was applied in the subsystem of the primary cyclone and the secondary feeder of a pulp and paper industry. This subsystem is part of the refining process in the manufacture of CTMP (Chemical Thermal Mechanical Pulping), which is used as raw material for the production of papers and is considered one of the most critical of factory lines. They were recorded in a period of 6 months, 36 incidents that resulted or not functional failures, representing $7.13 \%$ of failures occurred in the Refining of CTMP process.

The group responsible for analysis was made up of maintenance and operation members in conjunction with security professionals. After the team definition and establishment of objectives, a system operation study was raised with the help of all the technical documentation.

\subsection{Preparation Study}

The RCM deployment's goal was the selection and reduction in the number of incidents and functional failures related to the subsystem studied. Another objective is to create a system maintenance plan, assessing the general, carrying out a survey of the activities required by RCM.

\subsection{System Selection}

The process to be studied is a subsystem of CTMP manufacturing process, which is used as raw material for the production of paper towels, sanitary tissue, napkins and cards for different types of packaging. Specifically, the present study analyzes the sub-system of the primary cyclone and secondary feeder type lateral cap from the main line of the refining system (Figure 3). 
The RCM methodology is deployed aiming to identification of functions, failures, modes of failure, effects and their consequences, for the preparation of a maintenance action plan. This study is based on the operational context, simplified processes and components, described in the sequence.

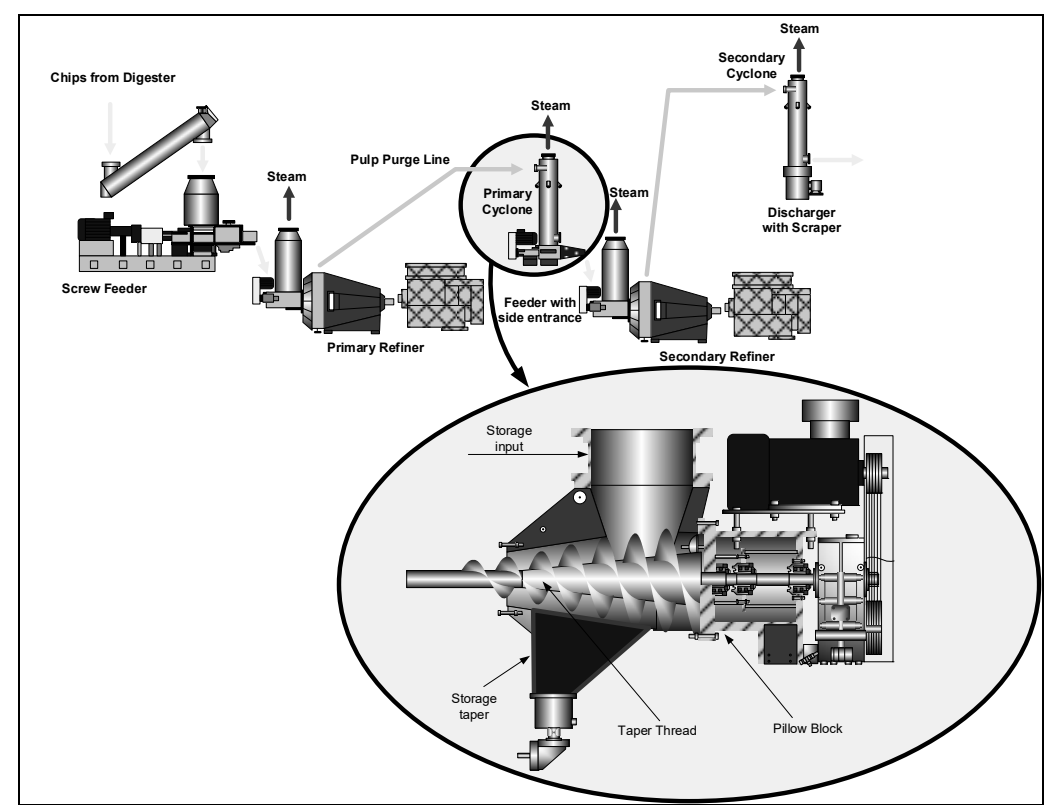

Figure 3: Subsystem of cyclone primary and secondary feeder

The primary function of the primary cyclone and secondary feeder type cap is to separate the paste from the vapor, which can be verified by measuring of pulp consistency, and feed the secondary refiner's conveyor thread. The slurry and steam mixture enters the cyclone tangentially near the top. Due to the centrifugal forces, the fibers accumulate along the wall of the cyclone and sink by gravity. Soon below the cyclone is the secondary feeder which takes the pulp to the thread conveyor which is a compression device that will finally direct the pulp to the secondary refiner.

This secondary feeder has a speed control to adjust the speed of the endless thread, according to a production rate, in order to allow for a homogenous feed to the refiner, a very important issue in this process. The screw housing is tapered, with the large end of the inlet side and the end smaller, restrictive, discharge side. As the pulp is transported through the secondary type feeder, it is compressed and limited in the conical section. The folder compresses a cap that limits water vapor from escaping from the refiner.

The process should be subject to seasonal stops (about 3 hours), and scheduled stops for maintenance. 
INDEPENDENT JOURNAL OF MANAGEMENT \& PRODUCTION (IJM\&P)

http://Www.ijmp.jor.br

V. 10, n. 6, November-December 2019

ISSN: 2236-269X

DOI: 10.14807/ijmp.v10i6.1009

\subsection{Analysis of the functions and failures}

The first step performed in identifying the functions was the establishment of a system description sheet, which contains information about the functions and parameters of the subsystem components, redundancy, protection devices and instrumentation details. From the functional diagram and the operation flowchart, the limits and boundaries of the analysis systems within the refining line were defined as a failure in the cyclone or feeder has a direct impact on the main system function.

The analysis of functions and functional failures was performed under the operating environment where the analysis subsystem has two main functions: (i) separating the steam folder and (ii) feed screw conveyor. The following secondary functions were also identified: (i) controlling the screw speed; (ii) protecting the feeder and sealing; (iii) stopping the engine in case of alarm.

Based on the primary functions of the system, five functional flaws have been identified: (i) does not separate the steam folder and not feed the tape thread secondary refiner; (ii) does not feed the secondary refiner homogeneously; (iii) forms a paste buffer to prevent steam leakage of the refiner; (iv) does not control the speed of the thread; $(v)$ does not protect the seal feeder.

\subsection{Selection of critical systems}

The primary cyclone and the secondary feeder part of the refining system in the main line of the pulp mill being classified as subsystems that line.

Based on the expert's experience, the critical parameters of the system were listed for the selection of the subsystems (first analysis) and components (second analysis). The ranking of critical subsystems and components is based on the result of the sum of the weights of each parameter (HEADQUARTERS, 2006; IEC, 2006). The critical parameters used were shown in the Table 1.

Table I. Parameters to selection of critical subsystems and components

\begin{tabular}{|c|c|c|c|}
\hline Effect & $\begin{array}{c}5 \\
\text { High }\end{array}$ & $\begin{array}{c}3 \\
\text { Medium }\end{array}$ & $\begin{array}{r}1 \\
\text { Low }\end{array}$ \\
\hline Safety & $\begin{array}{l}\text { Lesion with } \\
\text { removal }\end{array}$ & $\begin{array}{l}\text { Lesion without } \\
\text { removal }\end{array}$ & No risk \\
\hline Productivity (Down-Time) & More than $2 \mathrm{~h}$ & Between $2 \mathrm{~h}$ and $1 \mathrm{~h}$ & Less than $1 \mathrm{~h}$ \\
\hline Quality & External impact & Internal impact & No impact \\
\hline Environment & $\begin{array}{c}\text { External } \\
\text { contamination }\end{array}$ & $\begin{array}{c}\text { Internal } \\
\text { contamination }\end{array}$ & No contamination \\
\hline MTTR & More than $2 \mathrm{~h}$ & Between $2 \mathrm{~h}$ and $1 \mathrm{~h}$ & Less than $1 \mathrm{~h}$ \\
\hline
\end{tabular}


INDEPENDENT JOURNAL OF MANAGEMENT \& PRODUCTION (IJM\&P)

http://Www.ijmp.jor.br

v. 10, n. 6, November-December 2019

ISSN: 2236-269X

DOI: 10.14807/ijmp.v10i6.1009

$\begin{array}{lccc}\text { MTBF } & \text { More than } 6 & \text { Between 2 e } 6 & \text { Up to } 2 \\ \text { breakdown / year } & \text { breakdown / year } & \text { breakdown / year } \\ \text { Repair costs } & \text { More than } & \text { Between } & \text { Less than } \\ & \cup \$ 2.000,00 & \cup 1.000,00 \text { e } & \cup \$ 1.000,00\end{array}$

\subsection{Critical analysis of Failure Modes and effects}

After the identification of functional failures, the FMEA analysis was held by the standard form. In the spreadsheet, the effects / consequences of Failure Modes were associated with their causes by a sequential identification due to the Failure Mode of each component. This identification code forms the identification of the Failure Mode.

By applying the FMEA analysis 16 Failure Modes were found associated with functional failures of the analyzed systems. The analysis was restricted to a system with a small amount of equipment (these being critical to the refining process), so was chosen to lead all Failure Modes found for the selection of maintenance activities.

\subsection{Selection of maintenance activities}

The spreadsheet decisional and decisional scheme diagram was used for selection of the maintenance activities. First, the Failure Modes were classified according with their visibility during the operation and nature of their impact on the system. In worksheet, Decisional Diagram through the RPN, the applicability criteria and effectiveness of tasks and Decisional Diagram of Figure 8, the maintenance activities for each Failure Mode selected.

The Failure Modes with negligible risk (low RPN) were evaluated by the Decisional Diagram as a function of RPN, shown in Figure 4. As previously mentioned, the RPN is the result of the product between the severity of Failure Mode, the frequency and the level of detection (JIAN-MING et al., 2011; IEC, 2006; HUADONG; ZHIGANG, 2009).

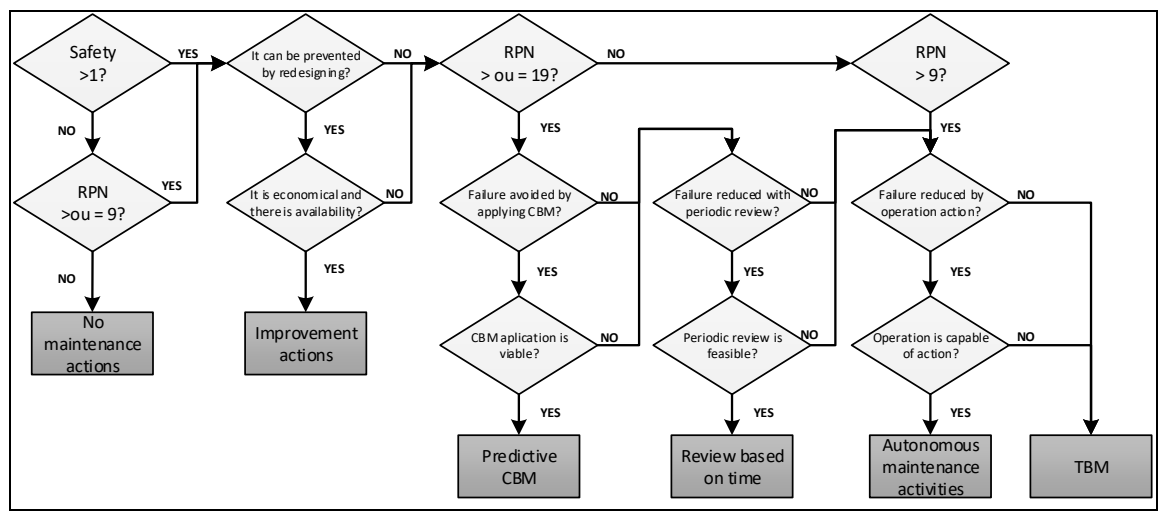

Figure 4: Decisional Diagram as a function of RPN 
INDEPENDENT JOURNAL OF MANAGEMENT \& PRODUCTION (IJM\&P)

http://Www.ijmp.jor.br

v. 10, n. 6, November-December 2019

ISSN: 2236-269X

DOI: 10.14807/ijmp.v10i6.1009

Using the Decision Diagram (Figure 4), the applicability criteria and effectiveness of tasks were identified 18 maintenance activities, documented in the decision spreadsheet with another information about each Failure Mode. The frequency of the tasks was based on the experience of analysts and maintainers, historical equipment, technical documentation and information from manufacturers.

All selected tasks were accepted as to its applicability and feasibility: 10 failure detection activities (2 of them carried out the operation), 5 predictive inspection activities, 1 activity of preventive replacement and 2 activities of design changes. The classification of Failure Modes and selection of activities can be observed in the Decision Diagram (Figure 5).

\begin{tabular}{|c|c|c|c|c|c|c|c|c|c|c|c|c|c|}
\hline \multirow{4}{*}{\multicolumn{5}{|c|}{$\begin{array}{l}\text { RCM } \\
\text { DECISIONAL } \\
\text { DIAGRAM }\end{array}$}} & \multicolumn{6}{|c|}{ Process: Manufacture of Paper and Pulp } & N.ㅇ & Coordinator: & Date \\
\hline & & & & & \multicolumn{6}{|c|}{ Line: CTMP } & 1 & - & $02 / 22 / 2017$ \\
\hline & & & & & \multicolumn{6}{|c|}{ Equipment: High Consistency Refining } & Rev. & Team & Page \\
\hline & & & & & \multicolumn{6}{|c|}{ Set: Primary Cyclone and Secondary Feeder } & 0 & RCM - CTMP & $1 / 1$ \\
\hline \multirow{2}{*}{\multicolumn{3}{|c|}{$\begin{array}{l}\text { Information } \\
\text { Reference }\end{array}$}} & \multicolumn{4}{|c|}{ Filter / Task } & \multirow{3}{*}{ 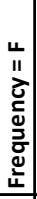 } & \multirow{3}{*}{ 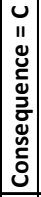 } & \multirow{3}{*}{ 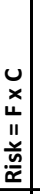 } & \multirow{3}{*}{\multicolumn{2}{|c|}{ Proposed Task }} & \multirow{3}{*}{ Task Frequency } & \multirow{3}{*}{ Performer } \\
\hline & & & $\stackrel{2}{\Perp}$ & $\stackrel{2}{2}$ & $\stackrel{\Delta}{2}$ & & & & & & & & \\
\hline $\mathbf{F}$ & $\mathbf{F F}$ & FM & 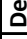 & 峁 & $\underline{2}$ & $\underline{2}$ & & & & & & & \\
\hline \multirow{3}{*}{1} & \multirow{2}{*}{ A } & $1 \mathrm{~A} 1$ & $S$ & $N$ & $\mathrm{~N}$ & $\mathrm{~N}$ & & & 0 & \multicolumn{2}{|c|}{$\begin{array}{l}\text { Create alarm in the SDCD to turn off the secundary feeder and stop the } \\
\text { plant if occur a protection motor system actuation. }\end{array}$} & Only & $\begin{array}{c}\text { Automation } \\
\text { Especialist }\end{array}$ \\
\hline & & $1 \mathrm{~A} 2$ & $\mathrm{~N}$ & $S$ & $N$ & $\mathrm{~N}$ & & & 0 & \multicolumn{2}{|c|}{$\begin{array}{l}\text { Task under condition / Monitore the motor conditions through } \\
\text { preventive inspections. }\end{array}$} & For three months & $\begin{array}{c}\text { Preventive } \\
\text { Maintenance }\end{array}$ \\
\hline & B & 1B1 & $N$ & $N$ & $\mathrm{~S}$ & $\mathrm{~N}$ & & & 0 & \multicolumn{2}{|l|}{ Task of disposal scheduled. } & - & $\begin{array}{l}\text { Mechanical } \\
\text { Especialist }\end{array}$ \\
\hline \\
\hline \multirow[t]{2}{*}{2} & A & $2 \mathrm{~A} 1$ & $S$ & $N$ & $N$ & $\mathrm{~S}$ & & & 0 & \multicolumn{2}{|c|}{$\begin{array}{l}\text { Instalation of a pressure sensor within the refiner to detect the failure } \\
\text { and to send a signal to the SDCD, that generates a alarm and act in the } \\
\text { control system. }\end{array}$} & Only & $\begin{array}{c}\text { Automation } \\
\text { Especialist }\end{array}$ \\
\hline & B & 2B1 & S & $N$ & $N$ & $S$ & & & 0 & \multicolumn{2}{|l|}{$\begin{array}{l}\text { Instalation of a torque sensor in the feeder to detects the } \\
\text { condition, stoping the motor and generating a alarm in }\end{array}$} & Only & $\begin{array}{c}\text { Automation } \\
\text { Especialist }\end{array}$ \\
\hline
\end{tabular}

Figure 5: Worksheet of RCM Decision Diagram

\subsection{Discussions}

To evaluate the RCM profits, a simple calculation methodology was defined. Final data was collected based on information available on Maintenance Management Information System (MMIS). A rational analysis was done using a Logic Model, that consists in a Failure Rate $(\lambda)$ calculation, before and after the RCM model implantation. Findings are analyzed to, finally, accomplish the final evaluation. The improvement tasks evaluation is shown in the Figure 6. 
DOI: 10.14807/ijmp.v10i6.1009

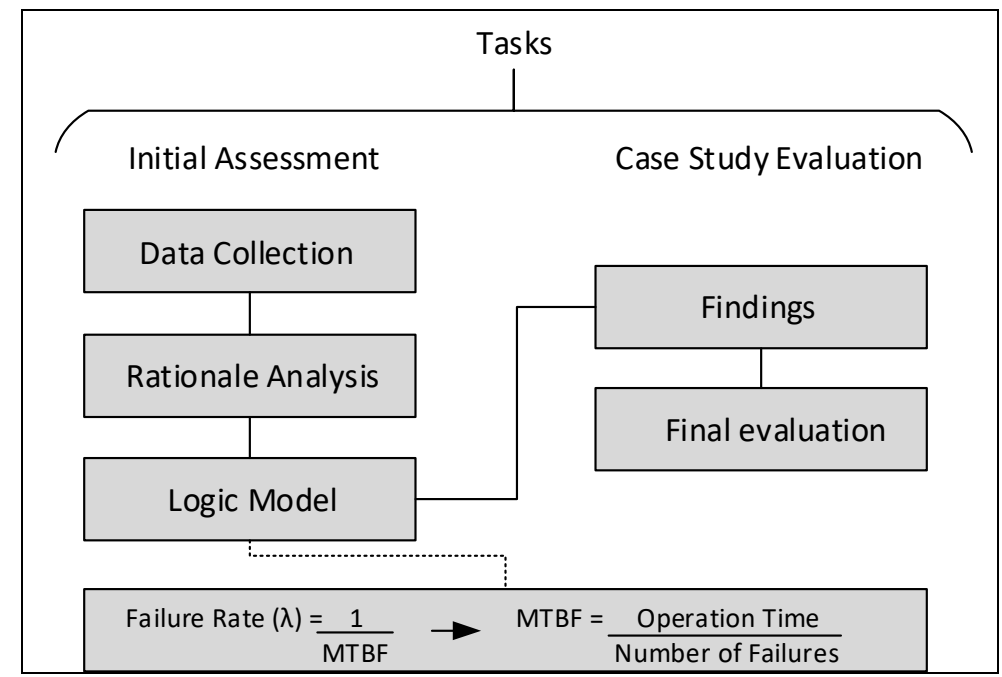

Figure 6: Improvement tasks evaluation

The information collected consists of data logs extracted from the MMIS. These data were processed and information was extracted for a verification of the current state of the studied system, as well as after the RCM deployment. In both phases, reliability parameters were identified and calculated as described in Table 2.

\begin{tabular}{ccc}
\multicolumn{3}{c}{ Table 2: Reliability parameters for RCM deployment analysis } \\
\hline Parameter & Description & Notation/Calculation \\
\hline UT & Up Time of the system & Hours \\
DT & Down Time of the system & Hours \\
T & Total Time of operation & $T=U T+D T$ \\
N & Number of occurred failures & Integer \\
MTBF & Mean Time Between Failures & $M T B F=\frac{T U}{N}$ \\
MTTR & Mean Time To Repair & $M T T R=\frac{D T}{N}$ \\
A & Availability of the system & $A=\frac{U T}{T}$ \\
$\lambda$ & Failure Rate & $\lambda=\frac{1}{M T B F}$ \\
R & Reliability of the system & $R_{(t)}=e^{-\lambda t}$
\end{tabular}

Initially, this system was monitored over a period of six months with the record of 36 occurrences that resulted or not in functional failures. This represents $7.13 \%$ of all the refining line failures. After the application of the new tasks and procedures of maintenance over a period of three months, 15 occurrences were recorded, equivalent to $5.43 \%$ of all the failures of the process. Of the all system there was a $23.7 \%$ reduction in the number of failures.

The main data collected and parameters calculated before and after the RCM deployment are presented on Figure 7. 
DOI: 10.14807/ijmp.v10i6.1009

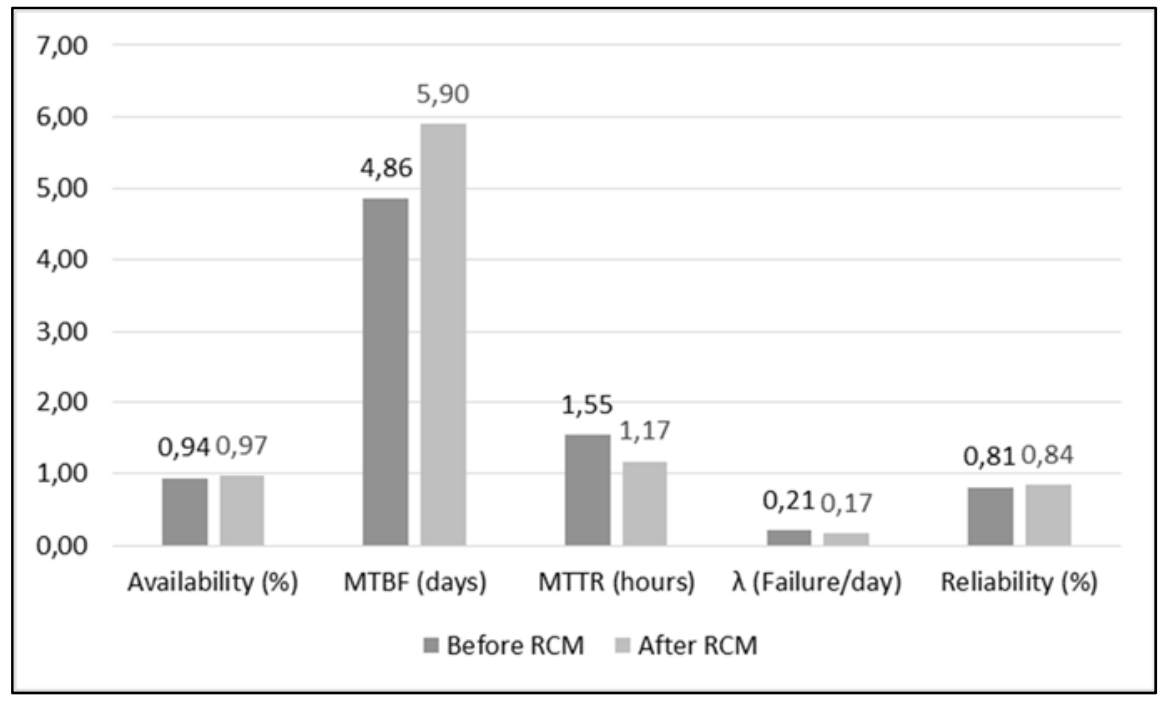

Figure 7: Final evaluation of the RCM deployment

The system availability enhanced after deployment due to the proportional increase in machine running time. The MTTR decreased, which shows indirect improvements in the quality of the maintenance team, justified by the possible motivation of the technical team in the implementation of improvements in the studied system. Also, due to the reduction in the occurrence of failures, the MTBF enhanced, directly impacting the decrease in the failure rate and the increase in reliability, from approximately 81 to $84 \%$.

During the review process and after its completion, a team of internal auditors was formed to evaluate the results and diagnose possible updates and / or deployment team of bug correction. As mentioned above, the RCM process, from a qualitative point of view, is not perfect and requires periodic adjustments after the first results. In addition, the system can be changed, such as by including new equipment, changing the procedures and redesigns, which may interfere with the implementation results.

As this case study, the RCM was established with the aim of creating a proper maintenance plan, being the audit team responsible to verify the implementation of the results over time, in a systematic and documented way and perform the necessary updates and revisions when necessary. The present system already had a maintenance plan defined.

However, it was outdated, without reference to its applicability, or historical and/or monitoring activities. The experience of the team, the history of the process, operating manuals, and technical documentation were extremely important for the definition of tasks. As a result, all of them were considered relevant and viable. 
DOI: 10.14807/ijmp.v10i6.1009

Based on the monitoring results of the Failure Modes and evaluation of maintenance, updates were made in RCM analysis, mainly related to periodicities of tasks.

\section{CONCLUSIONS}

Regarding the implementation of the RCM, the literature review identified the essential steps that will ensure the achievement of the objectives proposed by the RCM methodology. In this context, the customized model presented proved to be efficient, able to improve the selection of maintenance actions, reducing the failures occurrences and increasing the systems reliability.

During the analysis some difficulties were observed, such as the miscellaneous of practices in RCM methodology that generated delays and disabilities in the analysis. The lack of understanding of the methodology by some team members demonstrates the need for constant training for the analysts.

The identification of critical systems and components highlighted questions about security, environment and costs, that generates a new knowledge database that before was hidden and not described. The results were presented before and after the case study, through a Failure Rate and Reliability analysis, validating the efficiency of the proposed model.

The analysis focused on only the subsystem responsible for functional failure limited the failure analysis process only to the same limit. However, the maintenance frequency can be more effective by applying statistical methods and a deeper analysis of data.

The implementation of RCM programs is a significant step toward "taking full advantage" of the installed equipment. However, the heuristic approach is even, and its application requires experience.

\section{REFERENCES}

ALMANNAI, B. R.; GREENOUGH, R.; KAY, J. (2008) A decision support tool based on QFD and FMEA for the selection of manufacturing automation technologies, robotics and computer integrated manufacturing. Third International Conference on Manufacturing Research, v. 24, n. 4, 2008, p. 501-507.

BACKLUND, F. (2003) Managing the Introduction of Reliability Centered Maintenance, RCM - RCM as a method of working within hydropower organizations. Thesis (Doctoral) - Department of Business Administration and 
INDEPENDENT JOURNAL OF MANAGEMENT \& PRODUCTION (IJM\&P)

http://Www.ijmp.jor.br

v. 10, n. 6, November-December 2019

ISSN: 2236-269X

DOI: 10.14807/ijmp.v10i6.1009

Social Sciences - Division of Quality and Environmental Management, Lulea University of Technology. Lulea, $317 \mathrm{p}$.

BACKLUND, F.; AKERSTEN, P. A. (2003) RCM introduction: process and requirements management aspects, Journal of Quality in Maintenance Engineering, v. 9, n. 3, p. 250-264.

BAE, C.; KOO T.; SON, Y.; PARK, K.; JUNG, J.; HAN, S.; SUH, M. (2009) A study on reliability centered maintenance planning of a standard electric motor unit subsystem using computational techniques. Journal of Mechanical Science and Technology, v. 23, p. 1157-1168.

DEHGHANIAN, P.; AMINIFAR, F. (2013) A Comprehensive Scheme for Reliability Centered Maintenance in Power Distribution System - Part I: Methodology. IEEE Transactions on Power Delivery, v. 28, n. 2, p. 761-770.

DESHPANDE, V. S.; MODAK, J. P. (2002) Application of RCM to a medium scale industry. Reliability Engineering and System Safety, v. 77, n. 1, p. 31-43.

DHILLON, B. S. (2006) Maintainability, maintenance and reliability for Engineers. 1. ed. New York: CRC Press.

EN 13306. (2001) EN 13306: Maintenance terminology. The European Standard. Brussels.

FISCHER, K.; BERLING, L. (2012) Reliability-Centered Maintenance for Wind Turbines Based on Statistical Analysis and Practical Experience. IEEE

Transactions on Energy Conversion, v. 27, n. 1, p. 184-195.

GARZA, L. (2002) A Case Study of the Application of Reliability Centered Maintenance (RCM) in the Acquisition of the Advanced Amphibious Assault Vehicle (AAAV). Thesis (Master) - Naval Postgraduate School, United States Navy. California, 85p.

GUPTA, G.; MISHRA, R. P. (2016) A SWOT analysis of reliability centered maintenance framework. Journal of Quality in Maintenance Engineering, v. 22, $\mathrm{n}$. 2, p.130-145.

GUTIÉRREZ, A. M. (2005) Mantenimiento estratégico para empresas industriales o de servicios: enfoque sistémico kantiano. 1. ed. Colombia: AMG.

HEADQUARTERS. (2006) Failure Modes, Effects and Criticality Analyses (FMECA) for Command, Control, Communications, Computer, Intelligence, Surveillance, and Reconnaissance (C4ISR) Facilities. Technical Manual (TM 5698-4), Department of the Army, Washington, DC.

HEO, J. H.; KIM, M. K.; LYU, J. K. (2014) Implementation of Reliability-Centered Maintenance for transmission components using Particle Swarm Optimization. International Journal of Electrical Power \& Energy Systems, v. 55, p. 238-245.

HUADONG, Y.; ZHIGANG, B. (2009) Risk Evaluation of Boiler Tube Using FMEA. In: International Conference on Fuzzy Systems and Knowledge Discovery.

IEEEXplore Digital Library. p. 81-85.

JIAN-MING, C. (2011) The risk priority number methodology for distribution priority of emergency logistics after earthquake disasters. Management Science and Industrial Engineering (MSIE), International Conference On. Changsha, China, p. 560-562. 
KIM, J. H. (2009) Development of the FMECA Process and an Analysis Methodology for Railroad Systems. International Journal of Automotive Technology. Montreal, v. 10, n. 6, p. 753-759.

LEVERETTE, J. C. (2006) An Introduction to the US Naval Air System Command RCM Process and Integred Reliability Centered Maintenance Software. In: RCM 2006 - The Reliability Centered Maintenance Managers' Forum. p. 22-29.

MUDAVANHU, S. F. T. (2011) Application of RCM for a chipping and sawing mill. Journal of Engineering, Design and Technology, v. 9, n. 2, p. 204-226.

MCDERMOTT, R. E. (2009) The Basics of FMEA. 2. ed. New York: CRC Press. MIL-1629. (1980) Military Standard: Procedures for Performing a Failure Mode, Effects and Criticality Analysis. US Department Defense. Washington, DC.

MOBLEY, K. (2008) Maintenance Engineering Handbook. 7. ed. New York: McGraw-Hill.

MOBLEY, R. K. (1999) Root Cause Failure Analysis. 1. ed. Boston: ButterworthHeinemann.

MORAD, A. M.; POURGOL-MOHAMMAD, M.; SATTARVAND, J. (2014) Application of reliability-centered maintenance for productivity improvement of open pit mining equipment: Case study of Sungun Copper Mine. Journal of Central South University of Technology. v. 21, p. 2372-2382.

MOUBRAY, J. (1997) Reliability-centered maintenance. 2. ed. New York: Industrial Press Inc.

NASA. (2008) Nasa Reliability Centered Maintenance Guide. National Aeronautics and Space Administration. USA.

NAVAIR, 00-25-403. (2005) Management Manual: guidelines for the naval aviation Reliability-Centered Maintenance Process. Naval Air Systems Command. USA.

NAVSEA. (2007) Reliability Centered Maintenance (RCM) Handbook. S9081-ABGIB-010. Naval Sea Systems Command. USA.

PARK, G. P.; YOON, Y. T. (2012) Application of ordinal optimization on reliability centered maintenance of distribution system. European Transactions on Electrical Power, v. 22, p. 391-401.

SALONEN, A.; DELERYD, M. (2011) Cost of poor maintenance: A concept for maintenance performance improvement. Journal of Quality in Maintenance Engineering. v. 17, n. 1, p. 63-73.

SAMET, S.; CHELBI, A. (2010) Optimal availability of failure-prone systems under imperfect maintenance actions. Journal of Quality in Maintenance Engineering. v. 16, n. 4, p. 395-412.

SINHA, R. S.; MUKHOPADHYAY, A. K. (2015) Reliability centered maintenance of cone crusher: a case study. International Journal of System Assurance

Engineering and Management, v. 6, n. 1, p. 32-35.

SIQUEIRA, Y. P. D. S. (2009) Manutenção Centrada em Confiabilidade: Manual de Implantação. 1. ed. Rio de Janeiro: Qualitymark. 
SMITH, A. M.; HINCHCLIFFE, G. R. (2004) RCM: gateway to world class maintenance. 2. ed. Burlington: Elsevier Butterworth-Heinemann.

SMITH, A. M. (1993) Reliability-Centered Maintenance. 1. ed. Boston: McGrawHill.

SRIKRISHNA, S.; YADAVA, G. S.; RAO, P. N. (1996) Reliability-Centered Maintenance applied to Power Plant Auxiliaries. Journal of Quality in Maintenance Engineering, v. 2, n. 1, p. 3-14.

TSAROUHAS, P. H. (2011) A comparative study of performance evaluation based on field failure data for food production lines. Journal of Quality in Maintenance Engineering. v. 17, n. 1, p. 26-39.

WANG, C.; HWANG, S. (2004) A stochastic maintenance management model with recovery factor. Journal of Quality in Maintenance Engineering, v. 10, n. 2, p. 154-164.

WESSELS, W. R.; SAUTER, F. C. (2009) Reliability Analysis Required to Determine CBM Condition Indicators. In: Reliability and Maintainability Symposium. Fort Wort, p. 454-459.

ZAIONS, D. R. (2003) Consolidação da Metodologia de Manutenção Centrada em Confiabilidade em uma Planta de Celulose e Papel. Dissertação (Mestrado) Programa de Pós-Graduação em Engenharia de Produção, Universidade Federal do Rio Grande do Sul. Porto Alegre, 219p. 